\title{
PREVENTING AND COUNTERING VIOLENT EXTREMISM: LESSONS FROM SELECTED MUSLIM COUNTRIES
}

\author{
Mohd Mizan Aslam ${ }^{1}$ \\ ${ }^{1}$ Naif Arab University for Security Sciences (NAUSS), Riyadh, Kingdom of Saudi Arabia, e-mail: Maslam@nauss.edu.sa
}

(C)2020 by the authors. Submitted for possible open access publication under the terms and conditions of the Creative Commons
Attribution-ShareAlike 4.0 International License-(CC-BY-SA) (https://creativecommons.org/licenses/by-sa/4.0/)
\begin{tabular}{l|l|l|}
\hline do DOI : bttp:// dx.doi.org/10.30983/islam_realitas.v6i1.3152 \\
\hline Submission: 7 April 2020 & Revised: 31 May 2020 & Published: 30 June 2020 \\
\hline
\end{tabular}

\begin{abstract}
This paper explains the efforts of three Muslim countries, namely Yemen, Saudi Arabia and Malaysia in preventing and fighting against violence from jihadist extremism groups. De-radicalization program is understood as a process of changing the attitudes of former prisoners of terrorism to reject radicalism as a religious or political ideology that destroys national stability, and affects political and economic stability and even threatens human life. By using a qualitative approach, it was found that many countries have taken a significant approaches in dealing with the threat of terrorism through de-radicalization programs, especially in Yemen, Saudi Arabia and Malaysia. Most de-radicalisation programs are based on education and recovery. Education has the character of correcting misconceptions of politics and religion in militant activities, while the recovery strategy is more about continuous monitoring after liberation. The deradicalisation module aims at assisting these contries in militant recovery activities and also support their personal development. This paper explains the theoretical methods used in the de-radicalization programs in these three Islamic countries in the rehabilitation program. These countries use a set of tools that considers relevant factors such as holistic personality, self-reflection, social skills, criminal behavior, spirituality, security, and psychology.
\end{abstract}

Keywords: Deradicalization; Counterterrorism; Rehabilitation; Extremists; Jihadists.

\begin{abstract}
Abstrak
Tulisan ini menjelaskan bagaimana upaya pencegahan dan perlawanan terhadap kekerasan kelompok ekrimisme Jihadis berdasarkan pengalaman 3 negara Muslim yaitu Yemen, Saudi Arabia dan Malaysia. Program deradikalisasi dipahami sebagai proses mengubah perilaku tahanan terrorisme untuk. menolak radikalisme sebagai ideologi agama atau politik. yang merusak stabilitas nasional, dan berpengarub terbadap kestabilan politik dan ekonomi dan babkan ancaman kepada kehidupan manusia. Dengan menggunakan pendekatan kualitatif, ditemukan babwa banyak negara telah mengambil pendekatan yang signifikan dalam menghadapi ancaman terrorisme melalui program deradikalisasi terutama di Yemen, Saudi Arabia dan Malaysia. Kebanyakekan program deradikalisasi berasaskan pendidikan dan pemulihan. Pendidikan bersifat memperbaiki salah faham konsep berpolitik dan beragama dalam aktiviti militan, manakala strategi pemuliban lebih kepada pemantauan secara berterusan selepas pembebasan. Modul deradikalisasi bertujuan membantu kerajaan dalam kegiatan pemuliban militan dan juga membantu pembinaan personaliti mereka. Tulisan ini juga menjelaskan teoritikal metod yang digunakan dalam program deradikalisasi di tiga buah negara Islam ini dalam program rehabilitasi dengan menggunakan pendekatan personaliti bolistik, pembinaan kendiri, skil-sosial, penjenayahan, kerohanian, toleransi, keselamatan dan psikologi.
\end{abstract}

Kata Kunci: Deradicalization; Counterterrorism; Rehabilitation; Extremists; Jihadists

\section{Background}

Developments in recent years have revealed that the world is facing a global violent extremism challenge, which has become a major security issue for most countries around the world. This is because the issue of violent extremism dominates every single country regardless of locality and population size. In recent times, the concept of radicalization has increasingly been the subject of scientific studies. Leading to this is the fact that a universally accepted definition of the concept is yet to be developed and accepted by scholars. ${ }^{1}$

${ }^{1}$ Rohan Gunaratna and Hussin M.S, A Model of Terrorist Rehabilitation (London: Routledge, 2018), p. 124 Deradicalisation in Malaysia, International Case Studies of <https://doi.org/10.4324/9780429468445-8>. 
Nevertheless, a number of definitions have been developed by researchers to describe radicalization. These definitions are mostly centered around two different considerations: 1) on violent radicalization, where the emphasis is on the active pursuit or acceptance of violence as a legitimate means to attain stated goals; 2) on a broader sense of radicalization, where the emphasis is placed on the active pursuit or acceptance of far-reaching changes in the society which may or may not constitute a danger to democracy and may or may not involve the threat of or use of violence to attain stated goals. ${ }^{2}$ The Federal Bureau of Investigation (FBI) states that there are four stages of radicalization: pre radicalization, selfidentification, indoctrination, and action. Those four action have been explained extensively by Silber \& Bhatt. ${ }^{3}$ In a similar vein, Silber \& Bhatt identifies four phases of radicalization: the preradicalization phase, self-identification phase, indoctrination phase, and jihadization phase.

As long as a radical ideologies continue to exist in this world, there is the need for a specific remedy (deradicalization programmes) to mitigate and curb the effects. The need for it to be in place is essential for every country in order to maintain stability and social integration. In line with this, major steps have been taken by every nation block, such as the United Nations and European Union, as well as Southeast Asian countries. The steps lie on the principal approach for tackling deradicalization known as a 'strategy.' The strategy is based on Countering Violent Extremism or CVE. ${ }^{4}$ It was designed to cover the threat atmosphere and perimeters of deradicalization. It covers both the preventive

${ }^{2}$ Tinka Veldhuis and Jørgen Staun, Islamist Radicalisation: A Root Cause Model, Clingendael Security Paper (Amsterdam: Nederlands Instituut voor Internationale Betrekkingen 'Clingendael', 2009), p. 12 $<$ http://www.clingendael.nl/cscp/publications/papers/ ?id $=7740 \& \&$ type $=$ summary $>$.

${ }^{3}$ Mitchell D Silber and Arvin Bhat, 'Radicalization in the West: The Homegrown Threat,' The NYPD Jihadist Report (UK, 2007).

${ }^{4}$ Cameron Sumpter, 'Countering Violent Extremism in Indonesia: Priorities, Practice and the Role and corrective aspects of countering ideologies through law implementation with the active involvement of civil society organizations (CSO). The main objective here is to create an unsympathetic and unfavorable environment for terrorist operatives with the aim of isolating them from their supporters. ${ }^{5}$

In most cases, the main factor that exacerbates the menace of terrorism is ideology. Ideology is a strong force which could lead people to either act as a human being or an animal. Dealing with ideology is always an uphill task and difficult to overcome, given the world's experience in dealing with past ideologies like fascism, communism, and socialism. Currently, concerns have been raised as to how to deal with this long-standing problem known as terrorism. This is because the fight against terrorism often ends up with the loss of life, time, and money for so many years. ${ }^{6}$ These phenomena are detrimental to social harmony and threaten the whole world. If governments around the world fail to address the problem of terrorism as profoundly as it should, there could be a further deterioration of the problem with the possibilities of it affecting neighboring countries or elsewhere.

The existence of terrorism depends on two main things, ego and motive. Those who embrace radical and extreme ideology exist in a state of denial because they hardly agree with contrary opinions and, as a result, hold on to their views as the only truth. Normally, they do not subscribe to any opposing view or interpretations by scholars other than those with whom they share the same school of thought. The key problem is that terrorists keep

of Civil Society', Journal for Deradicalization, Summer.11 (2017), 112-47.

${ }^{5}$ Rohan Gunaratna and Mohd Mizan Aslam, Terrorist Rehabilitation and Community Engagement in Southeast Asia, Terrorist Rebabilitation and Community Engagement in Malaysia and Southeast Asia (London: Routledge, 2019), p. 23 < https://doi.org/10.4324/9780367817466-2>.

'Mohd. Mizan Aslam, The Role of CSO: Malaysia's Experience (Kuala Lumpur: Malay Press, 2019), p. 45. 
radical views inclusively, which often manifests through their extreme devotion to the opinions or 'fatwa' (legal opinions) of their own scholars or religious leaders (imams). Secondly, terrorism requires a political, social, ideological, and religious motive. Accordingly, those terrorists frequently have an explicitly political purpose and commit unlawful attacks for specific political agendas. The primary objective of many terrorists is the establishment of an Islamic Caliphate or Daulah Islamiyyah as advocated by ISIS, Al-Qaeda, Jemaah Islamiyyah (JI), Kumpulan Militan Malaysia (KMM), Jemaah Anshorut Tauhid (JAT), Abu Sayyaf Group (ASG), and many more organized and unorganized terrorist groups. ${ }^{7}$

The most effective remedy for curbing the menace of terrorism is to establish a deradicalization program as long as radical ideologies continue to exist in this world. This has become an imperative for every country in order to maintain stability and social integration.

The present paper is a theoretical study developed in order to understand the best practice of rehabilitation programs in Malaysia, Saudi Arabia, and Yemen. The strategy was designed to cover the threat atmosphere or perimeter. ${ }^{8}$ It covers both the preventive and corrective aspects of countering deadly ideologies through law implementation and the involvement of civil society organizations (CSO). The fundamental objective is to create an unsympathetic environment for terrorist operatives and an unfavorable environment for their supporters. Data analysis from various documents was used in order to understand the real concept of de-radicalization created by

${ }^{7}$ Mohd Mizan Aslam, A Critical Study of Kumpulan Militant Malaysia, Its Wider Connections in the Region and the Implications of Radical Islam for the Stability of Southeast Asia' (New Zealand: Victoria University of Wellington Press, 2009), p. 45.

8 Ahmad F. Yousif, 'Islamic Revivalism in Malaysia', American Journal of Islamic Social Sciences, 21.4 (2004), 30-56 <https://doi.org/10.35632/ajiss.v21i4.512>.

${ }^{9}$ Nicky R.M. Pouw and Ad De Bruijne, 'Strategic Governance for Inclusive Development', European Journal these countries. To achieve the main objective of the study, a thorough observation and compilation of information were used. However, this paper is not empirical in nature because it does not involve any testing or experiment in measuring rehabilitation effectiveness. Malaysia use Pemuliban, al-Hitar for Yemen and al-Hair in Saudi Arabia, these are the de-radicalization programs and will be precisely described in this paper.

\section{De-radicalization Perspective}

De-radicalization requires the long-term effort of various government departments as well as private agencies. Strategically, deradicalization initiatives consist of community engagements that aims at preventing extremists from nurturing terrorism-related ideas. ${ }^{9}$ Therefore, the de-radicalization program is an effort to help build social resilience rehabilitation and reintegration programs to deradicalize terrorists and extremists. While community engagement remains a crucial instrument for preventing extremism and disengaging terrorists from violent action, it also serves as a rehabilitation technique to tackle radical ideologies and misunderstood concepts such as jihad, takfiri, alkital and many more.. This is carried out by instilling appropriate defense mechanisms in the detainees and imparting universal values to prevent manipulation by terrorist organizations. The findings of the literature has shown that some countries are developing different facets of terrorist rehabilitation programs, ${ }^{10}$ focusing on the ideological, religious, educational, vocational, social, creative, and psychological issues that cause violent extremism. ${ }^{11}$ 
Every attack by violent extremists not only destroys lives, devastates families and communities, causes destruction of land and livelihoods; it also sows the seeds of intercommunal suspicion, intolerance and retaliation also contributes to global insecurity and instability. Despite increased securitization, surveillance, monitoring, and various counterterrorism programs, the problem shows no signs of abating but seems to increase every year.

While there may well be success stories of terror plots being foiled and radical individuals channeled into deradicalization programs, the unfortunate fact is that countless young people remain vulnerable to extremist propaganda primarily through social media. In Southeast Asia, many are particularly concerned about home-grown terrorists radicalized online and offline.

The issues related to terrorists and extremists, particularly militant IS (Islamic State) or Daesh, have opened up a new chapter in the world's view of Islam. They have also sparked the phenomena of 'Islamophobia.' In the context of IS or Daesh, their ideology has led to violence and actions that are incompatible with the true teachings of Islam. ${ }^{12}$ The mental disillusionment of the Muslim community itself has allowed their propaganda to spread effectively and quickly.

Hence, the understanding of these issues and relating issues pertaining to violence is necessary at every level of society. With this understanding, the elements of malice that infiltrate into society can be overcome and eliminated immediately. De-radicalization can be understood as the process of changing the attitudes and behaviors of former terrorists to reject violence as an ideological, religious, or political goal. However, many scholars have defined de-radicalization differently. According to Ashour, de-radicalization is "the process through which a radical group reverses its ideology and de-legitimizes the use of violent methods to achieve political goals while moving towards an acceptance of gradual political and economic changes within a pluralistic context."

Efforts of de-radicalization have given new impetus to former militants by teaching them how to lead a normal life and adhere to the religion that emphasizes the oneness of God, faith in the Unseen, encouragement to do good, shun evil, and rewards its followers by allowing them to go to heaven on the day of judgment as promised by God. In addition, de-radicalization is consistent with the teachings of all religions, especially Islam, which encourages every believer to practice moderation in all actions in order for them to earn rewards and enter paradise on judgment day as promised by God. Unfortunately, the ideology that is rooted in their radical teachings encourages the use of violence, risking the lives of innocent people. This represents nothing but the cruel wish to meet the demands, interests, and aspirations of unscrupulous individuals.

Meanwhile, Neumann explains the importance of society's acceptance of former terrorists a crucial element in the success or failure of de-radicalization programs. ${ }^{13}$ Most of the time, after the de-radicalization program isi completed and the former terrorists re-join society, it is difficult for them to get public acceptance due to the fears that society feels towards them. There is always the lingering suspicion that they might still not have fully recovered despite undergoing de-radicalization program, and that they might be nursing a private desire to return to the militant group. Public reluctance to accept former terrorists back into society could also reflect the perception that it is harder for former terrorists to disengage when they live in hostile and
12O. Ashour, 'Deradicalization Revisited', Washingtonpost (Washington, 2015).
${ }^{13}$ Peter R. Neumann, 'The Trouble with Radicalization', International Affairs, 89.4 (2013), 873-93 <https://doi.org/10.1111/1468-2346.12049>. 
troubled areas. Worthy of mention here, in particular, is the process of disengagement for someone who lives in a democratic society like Australia or Great Britain

\section{Comparative Deradicalization Method from Selected Countries}

This study will be focusing on the deradicalization initiatives taken by Saudi, Yemen, and the Malaysian governments who try to tackle Countering Violent Extremism (CVE) through terrorist rehabilitation approaches. These countries use democratic approaches and Islamic values that are combined with vacational skills. Geographically, these countries are located on a different continents; however, their approach is similar and practical.

A preliminary study, rehabilitation through building-wide networks of support, the government garnered volunteers from various government and NGO organizations as well as community engagement to participate in sivil society based deradicalization programmes. It is believed that the seven components of the program, named Modes of Rehabilitation, have been implemented as an essential component in Saudi, Yemen, and Malaysia's broader counterterrorism efforts. As stated by Director General of Prison Department of Malaysia, specific modules have been developed by experts from these countries through frequent coordination meetings. ${ }^{14}$

\section{Modes of Rehabilitation}

Malaysia, Yemen, and Saudi have been cooperating to devise the best practice on deradicalization programmes in their respective countries. A standard manual or modules have been developed within their localities. Local customs, cultures and religious practice of these countries are embedded in their deracalization model. In Malaysia, this specific program is called Pemulihan, al-Hitar in Yemen and al-Hair in Saudi, all of them are very special and tailored-made for achieving the best results. In order to understand further the deradicalization process employed by these three countries, Figure 1 below shows the components clearly.

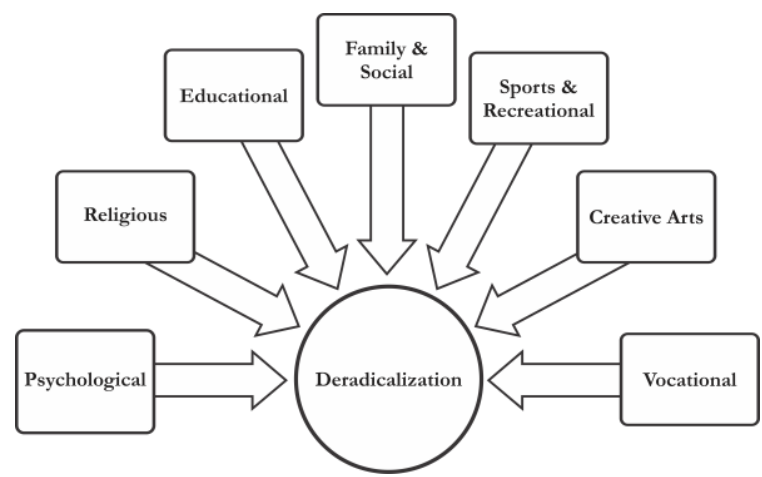

Figure 1: Global Deradicalization Approach. Source: Noor $(2009)^{15}$.

From Figure 1, there are seven modes of terrorist rehabilitation approaches currently employed by governments and agencies globally. Empirical evidence has also shown how different countries are developing different facets of terrorist rehabilitation programs. ${ }^{16}$ The varied rehabilitation models could focus on ideological, religious, educational, vocational, social, and psychological factos, as well as involving creative arts therapy, sports and recreation. ${ }^{17}$ These are implemented depending on the recommendations, availability of resources, and acceptance by the implementing bodies.

The Saudis, for example, have a comprehensive rehabilitation approach. The home secretary created a strategy known as the al-Hair, which is described as "a correctional rehabilitation institution intended to develop

${ }^{17}$ I.E. Putra and others, 'Increasing Integrative Complexity on Convicted Terrorists in Indonesia', Social Psychology and Society Coииальная Психология и Общество, 9.2 35-45 (2018),

<https://doi.org/10.17759/sps.2018090203>. Studies, 2009), p. 32 <https://www.pakpips.com/article/1554>.

${ }^{16}$ Gunaratna.
${ }^{14}$ Zulkifli Omar (Director general of Prison Department of Malaysia), Interview \{17 March 2018\}.

${ }^{15}$ Saba Noor and Shagufta Havat, Deradicalization: 
knowledge and behavioral skills through a set of programs delivered by advisors specialized in different areas of related sciences." ${ }^{\prime 18}$ The center offers four to six months of programs which include: psychological social therapy, history, art therapy, self-developmen,t as well as 'Online Engagement' as part of their rehabilitation initiatives. The voluntary government program, run under the auspices of the Home Affairs, is a program where qualified scholars are hired to enter online chat rooms to hold discussions with users on Islam. This caters especially for those seeking religious knowledge and clarification, wherein, for example, they may discuss the dangers of takfiri ideas ${ }^{19}$.

When implementing de-radicalization programs, each state has different concerns and considerations that will shape their choice of the framework as well as the contents of implementation. The Yemeni government, through al-Hitar program, has worked closely with the private sector as a facilitator of the rehabilitation of terrorists through a multifaceted program. ${ }^{20}$ They have rehabilitated and reintegrated hundreds of Syrian and Iraqi jihad alumni as well as terrorism-related convicts. These detainees went through intensive rehabilitation and were eventually transformed into productive citizens.

Al-Hitar rehabilitation program consists of three components: psychological rehabilitation, religious rehabilitation, and social rehabilitation. Throughout the detention period, detainees are regularly visited by psychologists who provide psychological counseling and assess their ability to cope with the mental stress of detainees. This allows psychologists to delve into the detainees' psychological reasoning, thus assessing their inclination for hatred and violence as well as susceptibility to radical influences. Trained psychologists are also involved in doing proper assessments of behavioral and cognitive aspects of the detainees' progress during rehabilitation.

Table. 1 Comparative Global Deradicalization Programs in Selected Countries

\begin{tabular}{|c|c|c|c|c|c|c|c|}
\hline Country & 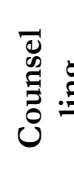 & 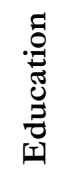 & 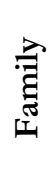 & 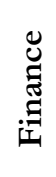 & $\begin{array}{l}\overrightarrow{0} \\
\frac{0}{0} \\
\dot{D}\end{array}$ & 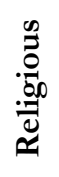 & $\frac{\mathscr{E}}{\tilde{E}}$ \\
\hline Malaysia & I & 1 & 1 & 1 & I & I & \\
\hline Indonesia & I & & I & I & / & & \\
\hline Singapore & / & I & / & & & I & \\
\hline Thailand & I & & & & & & \\
\hline Yemen & I & & & & I & 1 & \\
\hline Saudi Arabia & I & I & I & I & I & I & 1 \\
\hline Germany & I & & / & & & & \\
\hline Great Britain & 1 & & & & 1 & 1 & \\
\hline
\end{tabular}

Source: Aslam (2017) ${ }^{21}$

Manwhile, Malaysian deradicalization initiative was introduced through the Religious Rehabilitation Program. ${ }^{22}$ Most of the program is based on re-education and rehabilitation. Reeducation focuses on correcting political and religious misconceptions of the militants, while the strategy of rehabilitation is adopted to provide a thorough monitoring of the militants after their release ${ }^{23}$. The family members of the detainees are also engaged in the process as beneficiaries of financial support while the militants are in detention. After their release, militants are also assisted in their reintegration into society. This process contributes to a better

Multi-Ethnic Composition of Malaysia', International Journal on Minority and Group Rights, 13.1 (2006), 95-118.

${ }^{21}$ Mohd. Mizan Aslam, 'The Threat of Daesh in Universities: Malaysia's Experience', A Journal of the International Centre for Political Violence and Terrorism Research, 9.4 (2017), 13-16

${ }^{22}$ Nik Anuar Nik Mahmud, 'Krisis Sempadan Thailand-Indochina Dan Reaksi British', Jebat: Malaysian Journal of History, Politics and Strategic Studies, 26 (1999), 7383.

${ }^{23}$ Noor. 
understanding of the parties involved in the deradicalization program.

The main entity responsible for conducting deradicalization programs in Malaysia is the Royal Malaysian Police (RMP). The process involves a few stages. After the arrest of detainees, they are taken to the RMP (Special Branch Department) at Bukit Aman, Kuala Lumpur, for interrogation. The quality of the information obtained from the RMP is therefore assessed and processed, after which the detention of the detainees is recommended under the ISA for two years (minimum). However, what is presently obtainable is that the ISA is replaced by Prevention of Terrorism Act 2015 (POTA) and Security Offences (Special Measurement) Act 2012 (SOSMA). Depending on the information given by the detainees, this process may lead to more arrest, especially at this stage. The detainees are then confined to Restriction Order (RO) after release, while some may be subsequently released unconditionally. Some form of counter strategies are also implemented by the Malaysian government with the cooperation of the RMP (special branch department), the prime minister's department, the department of Islamic Development Malaysia and other relevant government agencies.

According to Malaysia's Inspector-General of Police (IGP), Datuk Seri Muhammad Fuzi Harun, as well as the then RMP Special Branch Director, rehabilitation and deradicalization programs in combating terrorism and extremist violence have shown a positive signs in Malaysia, since they have achieved almost 95 percent success rate. Most of the detainees that were released have been successfully reintegrated and returned to mainstream society, while only five percent of the released detainees were reported to have returned to

${ }^{4}$ Gunaratna.

25 Gunaratna.

26 R Gunaratna and M B Ali, Terrorist Rehabilitation: A New Frontier In Counter-Terrorism (UK: World Scientific Publishing Company, 2015), p. 43 their old way of life. The special branch director also said that the rehabilitation period must comply with legal provisions under the Prevention of Crime Act (POCA) and the Prevention of Terrorism Act (POTA) known as a protection order. In a bid to avoid a relapse situation that could jeopardize the nation's security, this provision is used to give as much support as possible to the detainees or their family members.

\section{Challenges in Terrorist Rehabilitation}

Although rehabilitation and reintegration initiatives from many countries like Saudi Arabia, Sri Lanka, Denmark, Yemen, and others have seen seen successes, many governments are still not willing to invest in the soft approach. ${ }^{24}$ Rehabilitation is a long-term commitment; it requires substantial resources and trained people to implement the programs. Rehabilitation is enduring, lost lasting and never-ending process. It is not only focused on inmates, it must be focused on future radicalized persons as well. The support system must be in place, and the state and society have to work hand in hand to tackle this issue. Educating society is vital. Skeptical attitudes and perception are the main obstacle in rehabilitation and deradicalization program in any place. ${ }^{25}$

In some countries, religion is seen as something that should remain in the private sphere. It is a fallacy to perceive religious rehabilitation as strictly focusing on religion. ${ }^{26}$ While counselors do preach about Islam, the program content is focused on deradicalization. The studies of the different country programs show that pulling someone away from extremism will not be successful unless all possible reasons that could have driven them to engage in violence and extremism are addressed. ${ }^{27}$ It is impossible to

$<$ https://books.google.co.id/books?id=0dy3CgAAQB $\mathrm{AJ}>$.

${ }^{27}$ Daniel Koehler, Understanding Deradicalization: Methods, Tools and Programs for Countering Violent Extremism, European Heart Journal, Contemporary Terrorism Studies (UK: 
guarantee that rehabilitation will bear a definite success in transforming the former terrorist to to a normal citizen. This would require a conscientious and well-planned implementation. ${ }^{28}$ Each detainee is unique in his path to radicalization, therefore, having dedicated case officers to address individual needs is a start to a new beginning.

These countries have developed their strategy in countering terrorism using the deradicalization model. This study has identified the best method that can be used by these countries and be exported globally. ${ }^{29}$ Both, hard and soft approached have their own advantages that is integrated in an indigenous context that is adaptive to local realities. I believe that the soft approach to countering terrorism must be positioned strategically. It is pertinent for governments to introduce both "preventive and corrective measures" in addressing violent extremism..$^{30}$ The challenges today are to ensure that the rehabilitated terrorists return to becoome full members of a larger community and contribute to their religion, ethnic group, and country ${ }^{31}$.

De-radicalization has to be pragmatic and dynamic. Those who are involved in extremism are always in a state of change. They can become talented and sophisticated because of social media and technologies. The spread of end-to-end encryption, Telegram, Twitter, and virtual private networks (VPNs), as well as dark and deep web, has significantly contributed to this problem. Rehabilitation has to implement all of these technologies in their programs in order to succeed. The new method needs to be embedded in its system in order to ensure the quality and effectiveness of the program. Countries that believe in this evolution have a bigger percentage of success compare to those who have not. Counselors, religious teachers, prison officers, and every individual involved in de-radicalization efforts have to be wellequipped to incorporate technology into their rehabilitation programs. ${ }^{32}$

Some of these terrorists are naive and know nothing about Islam. They only learn about the so-called true teachings of Islam through the internet and social media. Their access to the internet has changed the landscape of radicalization and terrorist attacks. Online platforms facilitate borderless radicalization and create more "lone wolf" attackers. ${ }^{33}$ Nowadays, radicalization is much easier than before. Terrorists does not need to be transported to the "jibad field" or conflict zones. It is enough to stay in front of a computer with internet facility. Instructions and communications that occurs through machines can end-up with bombings and brutal killings, as what occurred in the Nice truck attacks in 2016 and the Westminster attack in 2018. ${ }^{34}$

Saudi Arabia, Yemen, and even Malaysia have to be ready to de-radicalize returning jihadi fighters from ISIS headquarters in Syria and Iraq. But let us not forget those who come back from Afghanistan and Western countries. Most of these people are equipped with guerilla warfare tactics gained during their stay in those countries. ${ }^{35}$ The Maktab al-Kbidamah and Firqah, or special class for learning these skills, were implemented by terrorist groups such as $\mathrm{Al}$ Qaeda and ISIS in every single conflict zone. Moreover, these fighters also learned how to
Taylor \& Francis, 2006), p. 28 $<$ https:// books.google.co.id/books?id=9gp6DQAAQB $\mathrm{AJ}>$.

${ }^{28}$ Hussain Mohiddin Qadri, Countering Extremism and Building Social Resilience Through Community Engagement: South Asian Models (UK: World Scientific Publishing Company, 2013), p. 23 <https://doi.org/10.1142/9781908977540_0003>.

${ }^{29}$ Gunaratna.

${ }^{30}$ Neumann.
${ }^{31}$ Aslam, 'The Threat of Daesh in Universities: Malaysia's Experience'.

32 Gunaratna.

${ }^{33}$ Mohammad.

${ }^{34}$ Charles Mink, 'It's About the Group, Not God: Social Causes and Cures for Terrorism', Journal for Deradicalization, 5.Winter (2015), 63-91.

${ }^{35}$ Christina Hartmann, 'Who Does (Not) Belong to the Jihadis' Umma? A Comparison of IS's and Al Qaida's Use of Takfir to Exclude People from the Muslim Community.', Journal for Deradicalization, 2017, 213-42. 
make home-made bombs such as pipe and Tupperware bomb, which are very effective in killing people. ${ }^{36}$ Recently they also learned use phones and watchs as detonating bombs; this device was used in the Moovida Nightclub attack in Malaysia and Kuningan bombing by Taufiq Abdul Halim, a Malaysian exiled in Indonesia. Similar attacks are done by jihadists in Hodaidah, Mukalla \& Aden attacks, as well as the 2015 car bombing in Sana'a. Saudi Arabia, the home of Salafism which uses $17^{\text {th }}$ centuries reformists, Muhammad Abdul Wahhab's teaching as the main source ofr their school of thought, was to produce a significant number of terrorists. Since the 1960s scores of terrorist attacks occur each year ${ }^{37}$. Al-Yasmin attacks, AlQatif and Jeddah Suicide bombings were done by those who supported the ideology of ISIS $^{38}$

Most of the returning jibadi fighters will gather around and create more chaos and attacks in their homeland or any designated jihad battlefield in neighboring countries. The process of rehabilitating these fighters has to be monitored because of their ability in engaging in guerilla style of attacks as well as creating homemade bombings. This is a vital role by police personnel in monitoring and surveillance activities $^{39}$. However, the most stage of rehabilitation is the period after they have been detained.

In this respect, a specific and tailor-made de-radicalization program has to be in place. ${ }^{40}$ Well-equipped experts in handling returning extremists need to be hired by the Prison Department. Rehabilitation methods need to be changed if the previous method is considered unsuccessful. If the same method are used, the

36 Aslam.

${ }^{37}$ Mohd Mizan Aslam, A Model of Deradicalization in Malaysia.International Case Study of Terrorist Rehabilitation by Rohan Gunaratna \& Sabariab Husin (London: Routledge, 2018), p. 23.

${ }^{38}$ Fathali M Moghaddam, 'The Staircase to Terrorism: A Psychological Exploration.', American Psychologist, 60.2 (2005), 161. deradicalization objectives would not be achieved.

Malaysia proudly claim a $95 \%$ success rate in their deradicalization programmes. This is a high number compared to other countries including Yemen and Saudi. ${ }^{41}$ The luxury and leisure kind of rehabilitation style in Saudi completely not suitable in Malaysia's climate. Saudis, who are always living comfortably need a more relax and soft approach. This is implemented in most of their Terrorism Rehabilitation Programme, which is called AlHa'ir. On the other hand, the harsh and rough plans by of the prison officers of Yemen is much more suitable to Yemenis than to Malaysias. The former's program is called AlHitar. It is implemented by the Yemeni government to cater to returning jihadists as well as those involved in Houthi movement in southern Yemen. ${ }^{42}$

Another aspect of deradicalization that most governments do not really pay attention to is enforcement and legal aspects. Some countries like Malaysia, Singapore, and America have preventive laws such as Security Offences Special Measurement Act (SOSMA), Internal Security Act (ISA), and the Patriot Act. However, most countries in the world have no preventive law. Moreover, some countries violate preventive law in order to achieve their political objectives. United Nations Human Rights Office keeps telling Malaysia, Yemen, and Saudi Arabia in practicing the right of people should be protected by the law, otherwise, it can be abuse by any parties. ${ }^{43}$ Some of the colonial-era laws are no longer suitable in today's world and need to be changed. Terrorist inmates under this law have

\footnotetext{
${ }^{39}$ Richard J. Chasdi, Corporate Security Crossroads; Responding to Terrorism Cyberthreats, and Other Hazards in the Global Business Environment (UK: ABC-CLIO, 2018), p. 45

${ }^{40}$ Gunaratna.

${ }^{41}$ Mustafa Rusnan, 'Banteras Jenayah Rentas Sempadan', Utusan (Kuala Lumpur, 2017).

${ }^{42}$ Aslam.

${ }^{43}$ Ashour.
} 
a different mindset as they always think that they are not at fault. The right approach by not using hard approach is vital for the inmates ${ }^{44}$

\section{Conclusion}

In conclusion, it is safe to say that Saudi, Yemen, and Malaysia have developed their strategies in countering terrorism using a specific de-radicalization model. This study also identified the best method which can be used by these countries and exported globally. These countries have their own styles and advantages that are integrated in indigenous contexts that suit local realities. The soft approach and community engagement in countering violent extremism, including terrorism, must be positioned strategically. It is pertinent for governments to introduce both "preventive and corrective measures" in addressing violent extremism. The challenges today is how to ensure that terrorists who are rehabilitated are reintegrated in society and are able to contribute positively to their religion, ethnic group, and country.

Appropriate methods or programs such as de-radicalization have the potential to reduce societal involvement in developing militant propaganda, which is threatening the stability of national and international security, particularly in the Middle East and Malaysia. Improvement of existing modules in de-radicalization programs is crucial to instill patriotism among former terrorist prisoners in order to prevent other people from imitating their past actions. Furthermore, every entity should also look into the family or parents of the radicalized individuals. If the family is still radical, precautionary measures should be taken into account because there is a strong possibility that other children or adults can form a new breed of terrorists. In addition, by sharing the experiences of former terrorist prisoners, society can also raise awareness of the dangers

${ }^{44}$ Norliza Mohd Zain and others, 'Challenges and Evolution of Higher Education in Malaysia', UMRAN- of radicalism in order to avoid being stuck in unwanted situation.

The state has the primary responsibility of preventing and combating terrorism, while protecting human rights and fundamental freedoms. However, the state needs to also draw on the support of society in general, including civil society and businesses, to successfully counter the phenomenon of violent extremism. In countering violent extremism, participating entities have acknowledged the usefulness of such joint efforts in the form of public-private-community partnerships, particularly in the Southeast Asia region.

There has been a growing recognition that the broader public and local communities are stakeholders and partners in countering terrorism, rather than simply being the passive object of law enforcement activities. Southeast Asia is developing community-oriented approaches to countering terrorism that emphasize public support and participation in order to increase accountability and effectiveness. These approaches consist of locally tailored and locally-driven initiatives that draw on partnerships among a wide range of actors, beyond traditional security practitioners, to include other public authorities, as well as civil society organizations, businesses, and the media.

To conclude this discussion, it is clearly shown that the state that tries to meet the preventing countering violent extremism PCVE agenda has better opportunities but also faced big challenges. PCVE has a bright chance to become an important rehabilitation agenda in the future, especially when there is a drastic change in policy and law, as well as changes in the leadership of a country. In other aspects, howevever, PCVE contain many complications, especially when prominent actors fail to detect problems and develop clear policies in the implementation of related programs and 
activities. This situation can be overcome if the players or government and private agencies who are involved in de-radicalization, can create a clear understanding amongst the countries.

A more prudent and thoughtful approach should be taken by all of the states and entities who are involved in de-radicalization. The involvement of every entity in society, such as the women, children, teenagers, religious experts, entrepreneurs, and every individual within the community, is essential ${ }^{45}$. It is the responsibility of states to ensure that every unit of the community is involved and provided with a solid understanding of the issues at hand. This understanding has to be built and developed from the beginning, from school to university, followed by working life. This is even more important for children living in high risk conflict areas. In fact, when a living environments is surrounded by extreme and radical communities, individuals are in high rish situations and are in more need of awareness of and access to these programs.

From deradicalization approaches in Malaysia, Yemen and Saudi, we learn that deradicalization knowledge has to be nurtured, beginning with primary or secondary schools. This is where the importance of deradicalization will be exposed to students. Consequently, their projects or field studies will be to have direct exposure and hands-on experience with de-radicalization entities. In the long run, this will be the basis having more awareness and information regarding the importance of de-radicalization in maintaining the well-being of the society. This includes PCVE. Various communication mediums, including creating conventional classes and online classes, have become essential at this stage. Students need to build their ability to think critically. Mastering IT knowledge, having good social skills, and developing high emotional intelligence is the key to producing a generation that understands the importance of de-radicalization in society.

A more prudent and thoughtful approach should be taken by PCVE actors. This includes building a state-society partnership called Civil Society Organizations (CSO). The involvement of every entity in society, such as the women, children, teenagers, religious experts, entrepreneurs, and every individual within the community, is essential. It is the responsibility of the CSO to ensure that every unit of the community is involved and provided with a solid understanding of PCVE ${ }^{46}$ This understanding has to be built and developed from the beginning, from school to university, followed by working life. This is even more important for children living in high risk conflict areas. In fact, when a living environments is surrounded by extreme and radical communities, individuals are in high rish situations and are in more need of awareness of and access to CSOs.

It is clearly shows that CSO can be made a complementary subject, introduced in primary or secondary schools ${ }^{47}$. This is where the importance of $\mathrm{CSO}$ will be exposed to students. Consequently, their projects or field of studies will involve direct exposure and hands-on experience with CSO. In the long run, this will be the basis for raising awareness regarding the importance of CSO in improving the well-being of society. Young people are particularly prone to radicalization but are also easier to deradicalize. It is the task of government and NGOs to ensure that this group are safe and are educated properly. It is important to develop their understanding of PCVE.

Wives in Indonesia: An Interpretative Phenomenological Analysis', Qualitative Report, 23.6 (2018), 1334-46.

47 M.M. Aslam, 'The Role of CSO: Malaysia's Experience' in Countering Violent Extremism Forum, Paper, Kuala Lumpur, 9-11 th September 2019. 


\section{References}

\section{Books}

Aslam, Mohd Mizan, The Role of CSO: Malaysia's Experience (Kuala Lumpur, The Malay Press, 2019)

-, Rohan Gunaratna and Hussin M.S, A Model of Deradicalisation in Malaysia, International Case Studies of Terrorist Rehabilitation, (London: Routledge, 2018) <https://doi.org/10.4324/978042946844 $5-8>$

---------, A Critical Study of Kumpulan Militant Malaysia, Its Wider Connections in the Region and the Implications of Radical Islam for the Stability of Southeast Asia (New Zealand: Victoria University of Wellington, , 2009)

Chasdi, Richard J., Corporate Security Crossroads; Responding to Terrorism Cyberthreats, and Other Hazards in the Global Business Environment (UK: ABC-CLIO, 2018)

Gunaratna, R, and M B Ali, Terrorist Rebabilitation: A New Frontier In CounterTerrorism (UK: World Scientific Publishing Company, 2015)

-----, and Mohd Mizan Aslam, Terrorist Rehabilitation and Community Engagement in Southeast Asia, Terrorist Rehabilitation and Community Engagement in Malaysia and Southeast Asia (London: Routledge, 2019) $<$ https://doi.org/10.4324/978036781746 6-2>

Koehler, Daniel, Understanding Deradicalization: Methods, Tools and Programs for Countering Violent Extremism, European Heart Journal, Contemporary Terrorism Studies (UK: Taylor \& Francis, 2006)

Noor, Saba, and Shagufta Hayat, Deradicalization: Approaches and Models (Jakarta: The Institute of Peace Studies, 2009)

Qadri, Hussain Mohiddin, Countering Extremism and Building Social Resilience Through Community Engagement: South Asian Models, Imperial College Press Insurgency And Terrorism Series (UK: World Scientific Publishing Company, 2013) <https://doi.org/10.1142/978190897754 0_0003>
Veldhuis, Tinka, and Jørgen Staun, Islamist Radicalisation: A Root Cause Model, Clingendael Security Paper (Amsterdam: Nederlands Instituut voor Internationale Betrekkingen 'Clingendael', 2009)

\section{Journals}

Aslam, Mohd Mizan, 'The Threat of Daesh in Universities: Malaysia's Experience', A Journal of the International Centre for Political Violence and Terrorism Research, 9 (2017), 1316

Hartmann, Christina, 'Who Does (Not) Belong to the Jihadis' Umma? A Comparison of IS's and Al Qaida's Use of Takfir to Exclude People from the Muslim Community.', Journal for Deradicalization, 2017, 213-42

Mahmud, Nik Anuar Nik, 'Krisis Sempadan Thailand-Indochina dan Reaksi British', Jebat: Malaysian Journal of History, Politics and Strategic Studies, 26 (1999), 73-83

Mink, Charles, 'It's About the Group, Not God: Social Causes and Cures for Terrorism', Journal for Deradicalization, 5 (2015), 63-91

Moghaddam, Fathali M, 'The Staircase to Terrorism: A Psychological Exploration.', American Psychologist, 60 (2005), 161

Neo, Jaclyn Ling-Chien, 'Malay Nationalism, Islamic Supremacy and the Constitutional Bargain in the Multi-Ethnic Composition of Malaysia', International Journal on Minority and Group Rights, 13 (2006), 95-118

Neumann, Peter R., 'The Trouble with Radicalization', International Affairs, 89 (2013), 873-93 $<$ https://doi.org/10.1111/14682346.12049>

Porter, Elisabeth, 'Rethinking Women's Empowerment', Journal of Peacebuilding \& Development, 8 (2013), 1-14

Pouw, Nicky R.M., and Bruijne, 'Strategic Governance for Inclusive Development', European Journal of Development Research, 2.1 (2015), 481-87 <https://doi.org/10.1057/ejdr.2015.53>

Putra, I.E., F. Erikha, R.S. Arimbi, and A. Rufaedah, 'Increasing Integrative 
Complexity on Convicted Terrorists in Indonesia', Social Psychology and SосіеtуСочиальная Психология и Общество, 9 (2018), $35-45$ $<$ https://doi.org/10.17759/sps.20180902 03>

Rufaedah, Any, and Idhamsyah Eka Putra, 'Coping with Stigma and Social Exclusion of Terror-Convicts' Wives in Indonesia: An Interpretative Phenomenological Analysis', Qualitative Report, 23 (2018), 1334-46

Striegher, Jason-Leigh, 'The Deradicalisation of Terrorists', Salus Journal, 1 (2013), 19-40

Sumpter, Cameron, 'Countering Violent Extremism in Indonesia: Priorities, Practice and the Role of Civil Society', Journal for Deradicalization, Summer (2017), 112-47

Yousif, Ahmad F., 'Islamic Revivalism in Malaysia', American Journal of Islamic Social Sciences, $21 \quad$ (2004), 30-56 <https://doi.org/10.35632/ajiss.v21i4.51 2

Yusof, Abdullah, and Siti Norfariza Mohd Tawel, 'Penganjuran Tilawah Al-Qur'an Peringkat Antarabangsa: Sejarah dan Perkembangannya', Journal of Al-Tamaddun, 8 (2013), 15-25 $<$ https://doi.org/10.22452/jat.vol8no2.2 $>$
Zain, Norliz Mohd, Velantina Aspah, Normazni Abdullah, and Mansoureh Ebrahimi, 'Challenges and Evolution of Higher Education in Malaysia', UMR ANInternational Journal of Islamic and Civilizational Studies, 4 (2017)

\section{Report, news and interview}

Ashour, O., 'Deradicalization Revisited', Washingtonpost, Washington, 2015)

Aslam, M.M., 'The Role of CSO: Malaysia's Experience' in Countering Violent Extremism Forum, Paper, Kuala Lumpur, 9-1 ${ }^{\text {th }}$ September 2019.

Rusnan, Musta, 'Banteras Jenayah Rentas Sempadan', Utusan, (Kuala Lumpur, 2017)

Silber, Mitchell D, and Arvin Bhat, 'Radicalization in the West: The Homegrown Threat' The NYPD Jibadist Report', (UK, 2007)

Zulkifli, Omar (Director general of Prison Department of Malaysia), Interview $\{17$ March 2018\} 